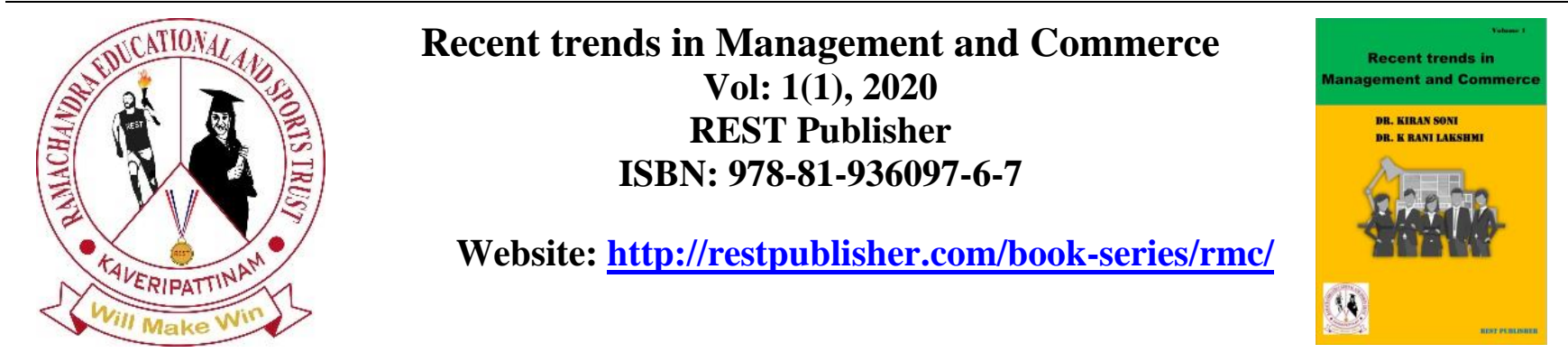

\title{
A Study on the Perception and Awareness among Millenials towards Cashless Economy with Special Reference to Kottayam District, Kerala
}

\author{
Sivanandini. S \\ Pondicherry University \\ sivanandini.sn9811@gmail.com
}

'Cashless India is the future India.'

\section{Introduction}

On November $8^{\text {th }}, 2016$, the government of India announced the demonetization as a step towards cashless economy. Cashless society is a futuristic vision which is being gradually introduced throughout the world. Such a substantial shift could never be performed overnight; therefore, the cashless society can be foreseen as the final point of a steady sequence of small steps, of whom many have already been undertaken, as cash is gradually being expelled from the modern society. Cashless transactions have made people to keep all their cash into bank and hence liquidity in banking system has increased. Also, it has stopped the flow of black money up to some extend. The other important advantage is that this situation will make people to pay their taxes in a transparent manner; hence government will have more money to run various schemes meant for the welfare of the public. India is a country where 98 percentage of the total economic transactions by the volume are done through cash. However, this may no longer be the case in future as the government has already steered the country towards cashless society. But the debate whether India can really transform itself into cashless economy or less cashless economy- as the government terms it-is referred to die down.

\section{SIGNIFICANCE OF THE STUDY}

Today's world is a digital world because it is ruled by the internet. Within the last decade or so, our world has become rapidly more digitalized. Thus, the concept of Digital India is being fulfilled to get a prominent position among other cashless economies. The increasing uses of mobile technologies have expected to pave their way for complete reliance on cashless transactions. In this current world, the relevance of cashless economy is increasing. Thus, an in depth study is needed to know to what extend society have accepted and is using the various modes of cashless transactions. This study is conducted among millennials (24-38 age group) of Kottayam district because they are more connected to technology and opts for convenience rather than traditional methods.

\section{OBJECTIVES}

1. To study the awareness and perception level among millennials towards cashless economy.

2. To understand the challenges faced by the users in cashless transactions.

3. To know the factors influencing the usage of e-transactions at the risk of frauds and security challenges.

4. To understand the influence of BHIM, Google Pay, Paytm, UPI, PhonePe and other modes of mobile apps on users.

\section{RESEARCH METHODOLOGY}

Research Design

The present study is descriptive and analytical in nature.

Coverage of study and sample design

The study is confined among the millennials in Kottayam district. The selection of the sample is based on convenience sampling. Samples from respondents are collected through questionnaire.

\section{Sources of data}

Both primary and secondary data is collected for the purpose of the study. Primary data is collected from millennials in Kottayam district through questionnaire had 20 questions including close ended questions, ranking questions, Likert scale questions and dichotomous questions. Secondary data is collected from various books, articles, websites and newspapers.

Tools for analysis

Percentage analysis, diagrammatic representation, Likert scale and rank by composite index was also used.

\section{LITERATURE REVIEW}

The paper discussed the consequences of transition to cashless economy. The transition lowers the cost of using money as a means of payment and increases state GDP. The study suggests that the central bank must regulate monetary policy to reduce the supply of cash in the economy.(Maurer, 2008)

The study revealed that when credit card- based payments are made, the volume, value and type of products purchased increases. The discussion paper presents research into the mode of payments effect on the purchase behavior and aimed to 
explore the relationship between the physicality of cash perceptions and purchase behavior. The paper concluded that consumers are aware and bothered about the actual amount or value of the goods if they pay with a cheque or cash than through a mobile phone. The paper also pointed out the influential factors such as cultural values and norms, age and experiences etc. affect the money perception and usage especially in smart cards.(Khan \& Craig-Lees, 2009).

The study shows that there is a possibility for a bright future of e-payments in South Arabia as major respondents favouredthe study. The study found out that the major concerns for mobile phone users are security of mobile payment transactions and unauthorized use of mobile phones. Mobile commerce and payments are being an important factor of the new digital economy as stated by Dmaima Bamasak. This paper discusses the status of mobile payments in relation with consumer's acceptance and concerns towards mobile payments.(Bamasak, 2011)

The study shows that growing use of electronic payments reduce physical vulnerability to crimes such as robbery and burglary. The paper tests the efficiency of EFT as a means of decreasing street crimes and assuring physical security. They found out that there is a negative significance and robust relationship between robbery and access to EFT. Law enforcements have concerned regarding the vulnerability of EFT system in relation to cyber-crimes.(Armey, Lipow, \& Webb, 2012)

The study stipulates the gradual movement of the payment system from physical cash to cashless society at all levels of personnel, corporate and governmental. He questions about the workability of the cashless society in the country, Nigeria where the financial systems are ill-equipped and not capable to implement the cashless society. He advocated that supportive human face must be adopted for the implementation of policies rather than career free force; it will only lead to worsen the financial system.(Alwaiye-Adams, 2012). Domagoj Sajter conducts a study on the phenomenon of the cashless society, critically analyzing the identity exposure and privacy concerns in electronic payment system. He argues that all the possible outcomes of a cashless society cannot be grasped because of moral hazards, security breaches and degradation of democracy. He also exposes the possible risk that a society would face in the future due to complete dependence on cashless transactions. (Sajter, 2013). The study focused on consumer's adoption status of mobile wallet and also examines market situations of mobile consumers towards mobile wallet. The study revealed that most of the respondents have knowledge about mobile wallets. It also identified that the influential factors such as ease and speedy transactions affect the adoption of mobile wallets. Security and privacy are the most concerns of the users.(Ngoc, 2014). The paper used theoretical model which only focused on benefits of going cashless in India. They examined sectors which can be easily adopted according with the cashless payment system. They arrived at the conclusion that cashless economy directly benefited at high maintenance cost, financial records and tax collections, financial inclusions and stopping leakages. The various factors such as mobile banking, removal of e-payment cost, GST, demonetization has played a favourable path, for implementing cashless economy in India.(Mukhopadhyay, 2014). They propounded that many digital currencies (also called crypto currencies) took its existence in online gaming communities or social media. The study extends mainly to Bitcoins. The risks related to virtual currencies including volatility risk, liquidity risk, technological and operational risk, legal risk etc. are deeply analyzed. They found out that only a relatively insignificant number of people use PayPal or other e- wallets in India.(Sharma \& Vyas, 2017). The study points out that cashless economy is the first important step towards the digital push. The study examines the importance of cashless society on banks performance by focusing on the problems of the cashless economy through SWOT analysis. The study shows that the cashless economy can be a game changer to reform the country from a cash-oriented economy. Thus, digitalization is said to have the potential of transforming India from a developing country to a developed country. The study also reveals that through cashless transaction banks all over has incurred losses and earned profits for its implementation.(Arora \& Kaushik, 2018)

ANALYSIS

AWARENESS LEVEL OF DIGITAL INDIA

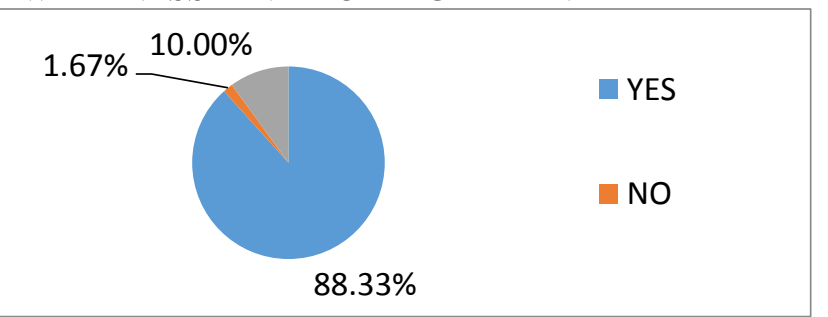

$88.33 \%$ of the total respondents are aware about Digital India whereas $10 \%$ are partially aware and only $1.67 \%$ are not aware. Thus, the level of awareness about Digital India is high among the respondents. From the table, majority of the respondents ie, $53.33 \%$ showed their opinion that India is not ready for cashless payment transactions, $33.33 \%$ and $13.33 \%$ expressed their opinion as partial and fully capable of India's readiness for cashless payment system. Therefore, the responses show that India is not completely ready for cashless transactions.

\begin{tabular}{|l|l|l|}
\hline Particulars & Frequency & Percentage \\
\hline Yes & 8 & 13.33 \\
\hline No & 32 & 53.33 \\
\hline Partial & 20 & 33.33 \\
\hline Total & $\mathbf{6 0}$ & $\mathbf{1 0 0 . 0 0}$ \\
\hline
\end{tabular}




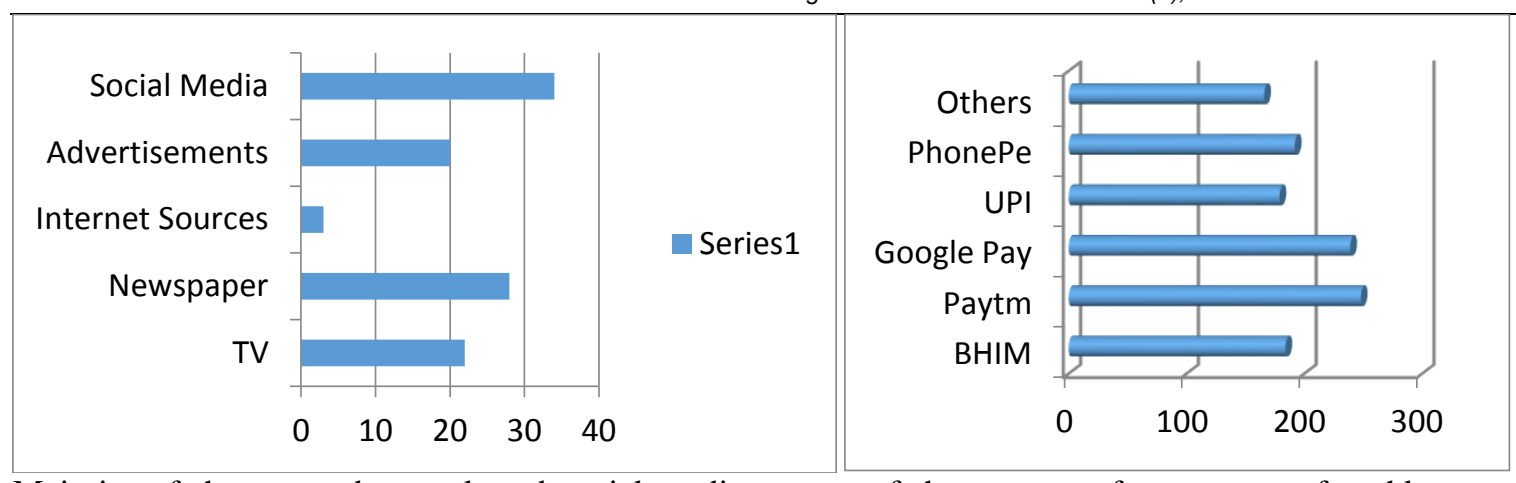

Majority of the respondents selected social media as one of the sources of awareness of cashless transactions which contributes the highest frequency and also respondents opted newspaper as the sources of awareness, advertisements, TV and internet sources as the other sources.

\begin{tabular}{|l|l|}
\hline Particulars & Ranks \\
\hline Debit /Credit Cards & 1 \\
\hline Internet Banking & 2 \\
\hline Mobile Apps & 3 \\
\hline Mobile Banking & 4 \\
\hline Digital Wallets & 5 \\
\hline POS & 6 \\
\hline
\end{tabular}

From the above Table, Debit/Credit cards are ranked $1^{\text {st }}$ as their awareness level is excellent and Internet Banking is ranked $2^{\text {nd }}$ as most of the respondents are comparatively highly aware while Mobile Apps ranked $3^{\text {rd }}$ and Mobile Banking, Digital Wallets and POS ranked $4^{\text {th }}, 5^{\text {th }}$ and $6^{\text {th }}$ position respectively. Hence, Debit/Credit cards were ranked high among other modes of cashless payment .And also same as ranked for usage level of various cashless transactions.From the analysis, Paytm was ranked $1^{\text {st }}$ as they are excellently aware from among various other Mobile Apps. Google Pay was ranked $2^{\text {nd }}$ followed by PhonePe, BHIM, UPI and others taking up $3^{\text {rd }}, 4^{\text {th }}, 5^{\text {th }}$ and $6^{\text {th }}$ respectively. While same as also ranked for the usage of various mobile apps. Thus, Paytm was ranked $1^{\text {st }}$ in both usage and awareness level from among various mobile apps.

\begin{tabular}{|l|l|l|}
\hline Particulars & Frequency & Percentage \\
\hline Security & 29 & 48.33 \\
\hline Poor internet connection & 5 & 8.33 \\
\hline Charges of online transactions & 12 & 20 \\
\hline Lack of infrastructure & 4 & 6.67 \\
\hline Merchant Acceptance & 1 & 1.67 \\
\hline Loss of personal data & 3 & 5 \\
\hline Lack of technical knowledge & 5 & 8.33 \\
\hline Others & 1 & 1.67 \\
\hline Total & 60 & 100 \\
\hline
\end{tabular}

Out of 60 respondents, 29 opted for security as their biggest concern followed by charges of online transactions with 12 responses. Poor internet connection and lack of technical knowledge were next concerns with 5 responses for both. Lack of infrastructure, loss of personal data, merchant acceptance and other factors have 4,3,1 and 1 respectively.

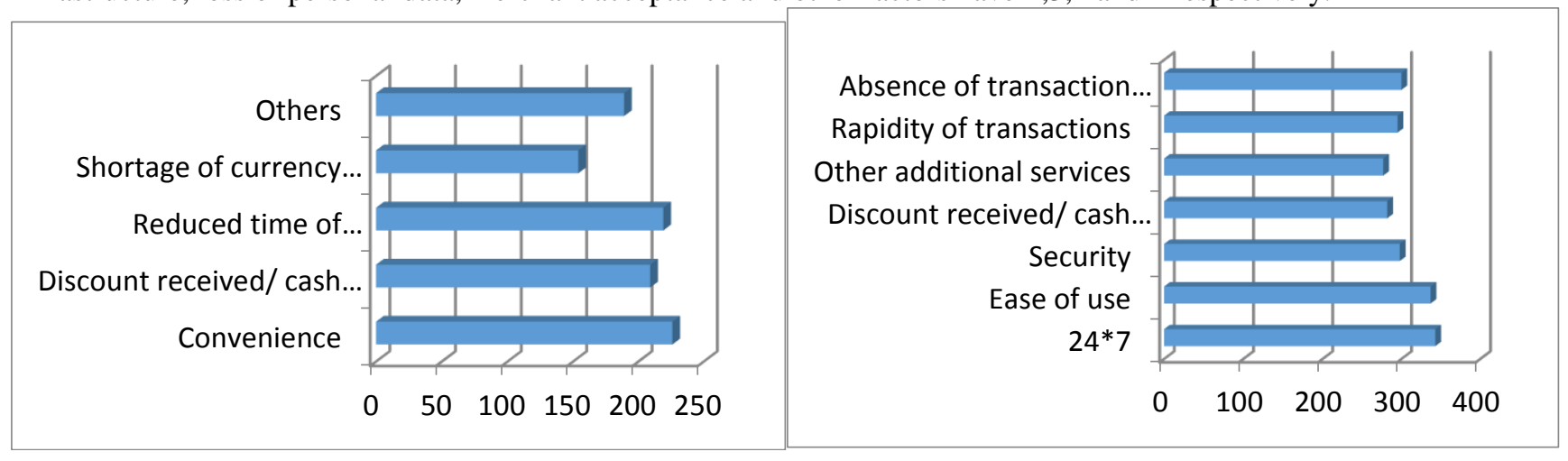


Convenience was opted as a major factor for adopting cashless payment system at the risk of fraud. Reduced time for transactions and discount received/ cash back offers were $2^{\text {nd }}$ and $3^{\text {rd }}$ important reasons for adopting cashless payments at the risk of fraud. The most influencing factor for usage of mobile apps was $24 * 7$ and the next following were opted as ease of use and absence of transaction cost and security feature respectively.

\begin{tabular}{|l|l|l|}
\hline Modes & Yes & No \\
\hline Debit/Credit Cards & 4 & 56 \\
\hline Mobile banking & 3 & 57 \\
\hline Digital wallets & 2 & 58 \\
\hline Mobile Apps & 5 & 55 \\
\hline POS & 1 & 59 \\
\hline Internet banking & 6 & 54 \\
\hline Percentage & $\mathbf{5}$ & $\mathbf{9 5}$ \\
& & \\
& & \\
\hline
\end{tabular}

Only 5\% of respondents were victims of cyber-crimes, out of it 6 respondents were victims of internet banking, 5 were of mobile apps, 4 were debit/credit cards.

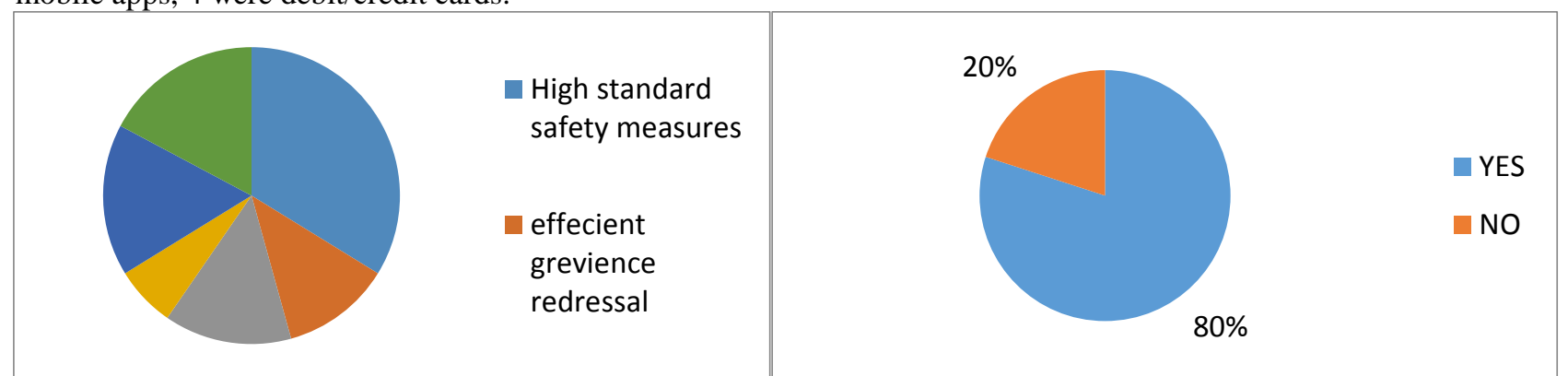

High standard safety measures are needed as the most wanted additional feature for effective cashless transaction. Good network system and timely refund policy were other important additional feature opted.

$80 \%$ of the total respondents have the opinion that the services provided by the banking institutions are trust-worthy. Whereas only $20 \%$ disagreed with the statement.

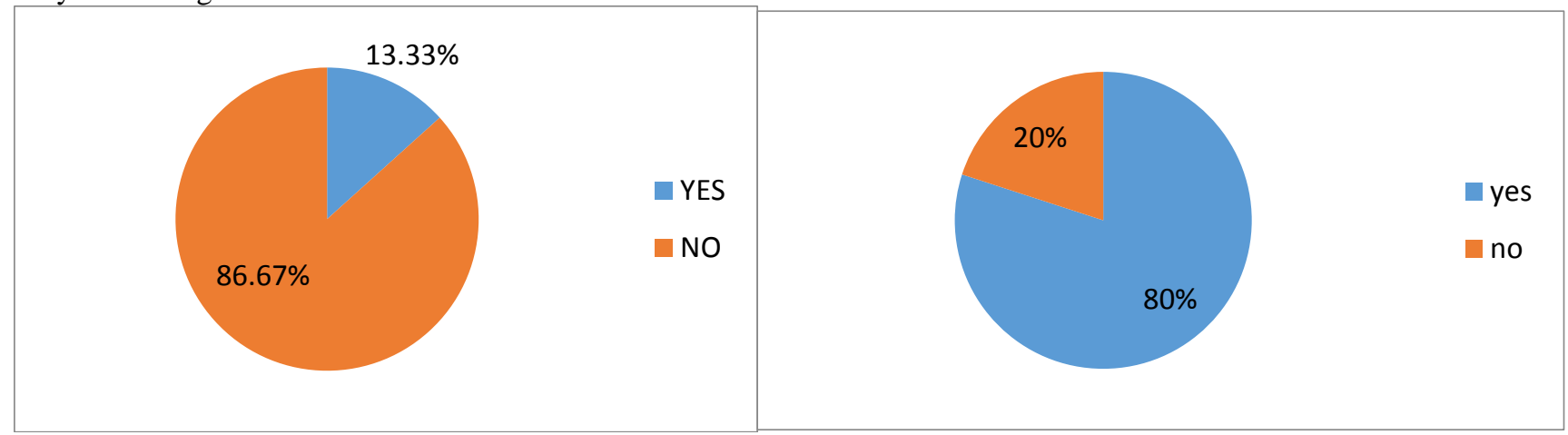

Only $13.33 \%$ of the respondents have participated in financial literacy campaign and rest $86.67 \%$ have never attended any financial literacy campaign.

\begin{tabular}{|l|l|l|}
\hline Particulars & Frequency & Percentage \\
\hline Yes & 28 & 46.67 \\
\hline No & 10 & 16.67 \\
\hline Maybe & 22 & 36.67 \\
\hline Total & 60 & 100 \\
\hline
\end{tabular}

$46.67 \%$ of the respondents have the opinion that making India cashless will uplift the standard of living and $36.66 \%$ of them opted that sometimes and $16.67 \%$ were against the statement that making India Cashless will uplift the standard of living. $80 \%$ of the respondents were willing to switch to cashless transactions while $20 \%$ were not willing and against the concept of cashless transactions.

\section{STATISTICAL ANALYSIS}




\begin{tabular}{|c|c|c|}
\hline \multicolumn{3}{|c|}{ Reliability Statistics } \\
\hline $\begin{array}{c}\text { Cronbach's } \\
\text { Alpha }\end{array}$ & $\begin{array}{l}\text { Cronbach's } \\
\text { Alpha } \\
\text { Based on } \\
\text { Standardize } \\
\text { d Items }\end{array}$ & $\mathrm{N}$ of Items \\
\hline .736 & .738 & 6 \\
\hline
\end{tabular}

Cronbach's Alpha measures the internal steadiness or consistency that is it shows how closely related a set of items are in a group. It is also known as a scale of reliability. Cronbach's Alpha 0.6 or above is considered as a reliable one and here it is 0.738 so it is reliable

\begin{tabular}{|c|c|c|c|c|c|c|c|c|c|c|}
\hline \multirow[b]{3}{*}{ Model } & \multicolumn{9}{|c|}{ Model Summary ${ }^{b}$} & \multirow[b]{3}{*}{$\begin{array}{l}\text { Durbin- } \\
\text { Waton }\end{array}$} \\
\hline & \multirow[b]{2}{*}{$\mathrm{R}$} & \multirow[b]{2}{*}{ R Square } & \multirow[b]{2}{*}{$\begin{array}{c}\text { Adjusted R } \\
\text { Square }\end{array}$} & \multirow{2}{*}{$\begin{array}{l}\text { Std. Error } \\
\text { of the } \\
\text { Estimate }\end{array}$} & \multicolumn{5}{|c|}{ Change Statistics } & \\
\hline & & & & & $\begin{array}{l}\text { R Square } \\
\text { Change }\end{array}$ & F Change & df1 & $\mathrm{df} 2$ & $\begin{array}{c}\text { Sig. F } \\
\text { Change }\end{array}$ & \\
\hline 1 & $.580^{\mathrm{a}}$ & .337 & 288 & .860 & .337 & 6.981 & 4 & 55 & .000 & 1.780 \\
\hline
\end{tabular}

Adjusted R-square explains how much independent variable are explaining dependent variable i.e. only $28.8 \%$ is explaining dependent variable. Durbin Watson is a test for autocorrelation through a statistical regression analysis and its value is around 2 , so there is no autocorrelation.

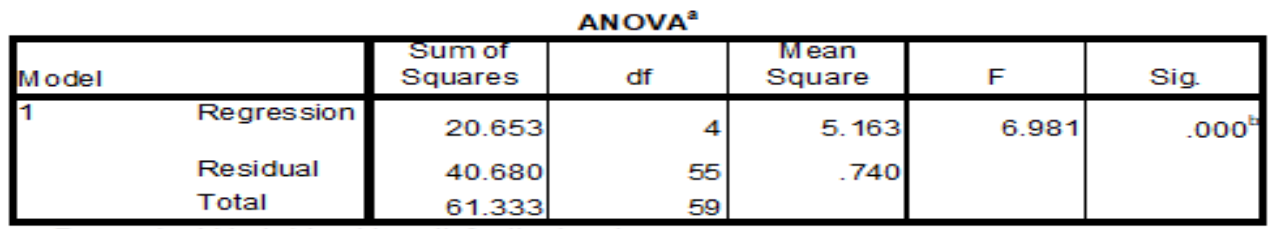

Anova shows whether the model is fit or not and here the model is fit and is significant at $1 \%$ level.

On the basis of data collected, analysed and interpreted from the responses to questionnaire the following findings, suggestions, and conclusions were made.

\section{FINDINGS}

A good number of respondents are well aware about digital India and only a few are not while only some had the negative opinion about the statement. A high percent of the respondents had the opinion that India is not ready for cashless payment transactions. The key source of awareness of cashless transactions were found to be social media followed by newspaper, advertisements, TV and rare sources include internet sources and others. Debit/Credit cards are ranked $1^{\text {st }}$ as their awareness and usage level is excellent and Internet Banking is ranked $2^{\text {nd }}$ as most of the respondents are comparatively highly aware while Mobile Apps ranked $3^{\text {rd }}$ and Mobile Banking, Digital Wallets and POS ranked $4^{\text {th }}, 5^{\text {th }}, 6^{\text {th }}$ position respectively. Hence, Debit/Credit cards were ranked high among other modes of cashless transactions. Paytm was ranked $1^{\text {st }}$ as excellently aware and also for usage among other mobile apps. Google pay was ranked $2^{\text {nd }}$ followed by PhonePe, BHIM, UPI and others taking up ranks $3^{\text {rd }}, 4^{\text {th }}, 5^{\text {th }}$ and $6^{\text {th }}$ respectively. The respondents opted security as their biggest concern followed by charges of online transactions. The other minor concerns were poor internet connection, lack of technical knowledge, lack of infrastructure, loss of personal data, merchant acceptance and others. Respondents opted convenience as the major factor for adopting cashless payment system at the risk of fraud. Reduced time of transaction and discount received/cash back offers were $2^{\text {nd }}$ and $3^{\text {rd }}$ reasons while other factors and shortage of currency notes took $4^{\text {th }}$ and $5^{\text {th }}$ reasons as for using cashless payment system even at the risk of fraud and security challenges. The respondents ranked $1^{\text {st }}$ position for $24 * 7$ as the most influencing factor for using mobile apps. Ease of use and absence of transaction cost were opted $2^{\text {nd }}$ and $3^{\text {rd }}$ while security feature and rapidity of transactions were ranked $4^{\text {th }}$ and $5^{\text {th }}$ position respectively. Discount received or cash back offers and other additional services were the least influencing factors and took position $6^{\text {th }}$ and $7^{\text {th }}$ respectively. A negligible percentage of respondents were victims of cyber - crimes which includes crimes through internet banking, mobile apps, debit/credit cards, mobile banking, digital wallets and POS. Majority of the respondents stated that high standard safety measures are needed as the most wanted additional feature for effective cashless transactions. Good network system and timely refund policy were the other additional features highly needed by the respondents. Cost reduction, efficient grievance redressal and other additional features were opted as the subsequent features. A high percentage of the total respondents have the opinion that the services provided by the banking institution are trust-worthy. Whereas only a lesser percentage disagreed with the statement. Only a few of the respondents have participated in financial literacy campaign, rest of the respondents has never attended any financial literacy campaign. Cash was the most used mode of payment for meeting regular household expenses. Debit/Credit cards and mobile payment apps were next used mode of payment. Internet banking and mobile banking were less used comparatively as mode of payment. Majority of the respondents had the opinion that making India cashless will uplift the standard of living and only a negligible percent disagreed with the statement. Many of the respondents were willing to switch to cashless transactions while a minor percentage was not willing and against the concept of cashless transactions.

\section{SUGGESTIONS}


Financial literacy campaign should be conducted more frequently to create more awareness about cashless transactions among millennials. The government should take measures for effective implementation of Digital India which will enable the Indian society ready for cashless transactions. Modern modes of cashless transactions like digital wallets, mobile banking and mobile apps should be made more user friendly. Mobile apps should adopt attractive offers and discounts, especially for petty transactions such as for payment of regular household expenses. For effective cashless transactions additional features such as high standard safety measures, timely refund policy and effective grievance redressal must be put into operation. Most of the respondents are willing to switch to cashless transactions but there are concerns which limit its adoption. Hence, actions against the biggest concerns of using cashless transactions such as a security, loss of personal data, lack of technical knowledge etc. should be made. Marketing and promotion programs should be conducted to create awareness among nonusers of cashless transactions.

\section{Conclusion}

There is an immense need to move towards a cashless economy in India. Most importantly it will help the government to achieve the dream 'Digital India'. Only a negligible percentage of all consumption expenditure was incurred through cashless transactions. Therefore, more steps are still to be adopted to completely build a cashless economy. Society agrees with the government on the usefulness of cashless economy as it helps to fight against terrorism, corruption etc. But one of the biggest problemis the working of cashless transactions in India is cyber-crime and illegal access. Therefore, it is important to strengthen internet security from protection against online fraud. True, there are difficulties in implementing the idea of cashless economy in vast country like India where many people are living under misery and poverty, yet a beginning had to be made some day. Today there is a sea change in the mindset of people regarding digital means of monetary dealings which are safe, easy, convenient and transparent. A part of digital India programme, the concept of cashless of cashless economy in India have empowered several modes of cashless transactions like credit/ debit cards, mobile wallets, UPI, internet banking etc. which will lead India to cashless in near future. Post demonetization, the people have finally started believing the power of plastic money in the form of credit/ debit cards and other channels of electronic payment. In conclusion, Digital India is not a distant dream but a plan in action.

\section{References}

Alwaiye-Adams, A. (2012). Evaluating the systematic transition to a cashless economy in Nigeria. The Electronic Journal of Information Systems in Developing Countries, 13(1),175-186.

Armey, L., Lipow, J., \& Webb, N. (2012). The impact of electronic financial payments on crime. Journal of payment strategy and systems, 3(1) pp:60-70.

Arora, B., \& Kaushik, N. (2018). Cashless economy : A key to digital proliferation in Indian banks. International Journal of Creative Research Thoughts(IJCRT), 142-149.

Bamasak, D. (2011). Exploring consumer's acceptance of mobile payments- an empirical study. International Journal of Information Tecnology, Communications and Convergence, Volume.1, Issue 2.

Khan, J., \& Craig-Lees, M. (2009). Cashless transactions: Perception of money in mobile payments. International Business \& Economic Review, vol.1,n.1.

Maurer, R. (2008). The increasing leverage of central bank cash in transition to a cashless economy: A DSGEM analysis. SSRN Electronic Journal, 109-118.

Mukhopadhyay, B. (2014). Moving from cash to cashless: Challenges and opportunities for India. Commonwealth Journal of Cmmerce and Management Research(CJCMR), 64-69.

Ngoc, D. (2014). Consumer adoption in mobile wallets: A study of consumers in Finland. Journal of International Business and Management, 30-35.

Sajter, D. (2013). Privacy,Identity and Perils of the cashless society. Journal of Monetary Economics, 97-103.

Sharma, N., \& Vyas, R. (2017). Virtual currencies: A hazard or a boon? A perspective from the digital finance ecosystem and associated legal issues. National Journal of Multidisciplinary Research and Development, volume-2, issue- 3. 